\title{
IMPROVING STUDENTS NARRATIVE WRITING PROCESS THROUGH SERIES OF PICTURE CLASSROOM ACTION RESEARCH
}

\author{
Yani Cahyani ${ }^{1}$, Dede Mita Nurjanah ${ }^{2}$ \\ ${ }^{1}$ IKIP Siliwangi \\ ${ }^{2}$ IKIP Siliwangi \\ ${ }^{1}$ Cahyaniyani63@gmail.com, ${ }^{2}$ Mithasutiawan7@gmail.com
}

\begin{abstract}
This research is done to know the benefits of using series of pictures in the process of narrative writing. It is also expected by the teacher to know that using series of picture, the students can be stimulated to think cratively in gaining the ideas and learning the narrative writing well. The method of the research quasi-experimental design to see the effectiveness series of picture toward students 'writing skill in narrative text. The population of this reserach was twelfth grade students of SMK Negeri 1 Cijati Cianjur and the sample was class XII. The data was collected by using pre-test and post-test measurement on the control and experiment class and comparing the gained scores between both classes. The result presented that the picture series as media in writing narrative text is effective towards students'writing skill in narrative text. The result of calculation presented that in the significance degree of $5 \%$, the value of t-test (to) $>\mathrm{t}$-table (tt) (5.514> 1.992). According to the criteria of the test, the result showed that there is a significant diferrence between students'writing skill in narrative text by using picture series as media and without picture series.it means that, the picture series is effective and applicable as the media in writing narrative text.
\end{abstract}

Keywords: Narrative Text, Series of Picture

\section{INTRODUCTION}

Writing is often understood as a difficult skill to master. Students learning the writing skill acquire to deal with the elements of writing. Blanchard and Root (1998: 1) as cited in Mundriyah \& Parmawati (2016) state that learning to write in a new language is not always easy. (Heaton, 1995) stated that skill is complex and sometimes difficult to teach, require mastery not only grammatical and rhetorical devices but also of conseptual and judgmental elements. Then, according to (Harmer, 1991) on his book The Practice of English Language Teaching, he states each skill has difficulties for students but writing has become the most complicated skill to be learned because writing is production skill and need a feedback. In the word, the students need to be able to improve the ideas, organize the text context, employ the suitable grammar, choose the lexical and structure forms, and present the suitable punctuation and spelling based on the text.

Dealing the difficulties in the writing are able to be finished by using the strategies especially in the process of teaching writing. The strategies must make the students can improve the students' writing skills, Moreover, the strategies are acquired to give the ability especially in encouraging the students to write and let them to need all practices in training the writing skill therefore the difficulties faced by the students can be solved well. 
The strategies of teaching the writing skill can have many kinds. Teaching may use teaching media as their Strategies to support them presenting the materials. Using teaching media is not morely about using the supporting equipments used in the situation of classroom. The teacher must choose suitable teaching media in order to achive the advantages of using teaching media. The media should be choosen by considering the goals of the lessons and the students characters. There are several aspect that should be chosen considered in choosing teaching media: the age, in of the interest, type of intelligence and experience of the students; the physical circumstances of the classroom; the cost of the media; and convenience of the materials available (Wright, 1989).

Based on the factors, the teacher is able to decided the teaching media which is suitable to use in the suitable pocess of teaching and learning in the classroom. The supported equipments can be choosen by using the suitable teaching media. One of the suitable teaching media is the use of the pictures. They are easily used and practiced.

As the suitable teaching media, the media of pictures can be showed in several ways, Besides showing the media of the picture as a picture, showing the media of pictures in style of pictures series are also a suitable media. Moreover, the teacher is able to utilize the series of pictures to teach the students in understanding the writing skill in well-organized text. The series of pictures contains a number of pictures that are joined into one another to explain certain events. In referring to the teaching process of writing the narrative text, a series of pictures is very suitable to utilize. The series of pictures is able to support the suitable process of teaching writing narrative text. In the relation to it, the teacher is able to begin by presenting the pictures meia when introducing the genre and describe the pictures media in a series which refers to the steps of events in the process of story things. presnting the series of pictures before the students implement the process of writing, especially the narrative text also can make the students foretell the steps of the events which are happened based on the sequences of the story. Later, when the students involve in the process of the writing stages, the series of pictures can be expected to make the students set the events of the story related to the picture arrangements with suitable structures. At the final process, the students are able to write a narrative story based on well-organized events.

Considering the result explained above, the reseacrh is held to search the advantages of using series of pictures in narrative writing and to know the students' attitudes through utilizing the series of pictures in narrative writing learning process.it can be expected that the research can be one of references especially for the teachersto make the students interesting and enjoyable inlearning the writing narrative therefore the students can be encouraged to write well . It is also expected that by using pictures, the students are able to be encouraged to learnd and think creatively in gaining the ideas and learn the narrative writing well.

In this paper,the writer focused on the effect of implementation of the series of picture in improving the student skill in writing narrative text at SMKN 1 Cijati Cianjur in academic year of 2016/2017. According to (Oshima, 2007), a narrative is the kind of writing that you do when you tell a story.use time order words and pharases to show when each part of the story happens. Also according to Phar and (Pharr, 2005, p. 174), they stat that the success of a personal narrative essay based on the seach significance. The narrative essay tells a story,to be sure,but the true value of the narrative gives the readers or listeners a moral value in every story. It is differentiate with other kinds of passages. 
In this paper,the writer focused on the effect of implementation of the series of picture in improving the student skill in writing narrative text at SMKN 1 Cijati Cianjur in academic year 2016/2017. According to (Oshima, 2007, p. 35), a narrative is the kind of writing that you do when you tell a story.use time order words and pharases to show when each part of the story happens. Also according to(Pharr, 2005, p. 174), they stat that the success of a personal narrative essay based on the seach significance.The narrative essay tells a story,to be sure,but the true value of the narrative gives the readers or listeners a moral value in every story. It is differentiate with other kinds of passages.

Writing is a skill of English language which requires students to represent and develop their own idea in a written form. Many students feel confuse on how to begin to write a paragraph or get stuck on constructing certain genre of the text. To be able to write well can be difficult even for the professionals. In writing skill, students have to be able to create their idea in writing. It was not interesting enough for the students. They did not have inspiration or idea in writing. When students write something while they are also collecting things like facts and concepts, it leads them to uncover something new.

According to (Wright, 1989, p. 35) on this book Pictures for Language Learning stat that, "picture are not just an aspect of method, but through their representation of places, objects, and people they are essential part of the overall experience "'it means that, pictures can help the learners to understand the meaning of a word because it represents the meaning of it.(Raimes, 1983, pp. 27-28). Said that pictures will bring everthing the outside world into the classroom in a vividly concrete way.

\section{METHOD}

The design of this study was quasi-experimental design. The writer used quasi-experimental design of this study to see the effectiveness of picture series towards students' writing skill in narrative text. According to (Miller, 2006), the purpose of quasi experimental design is to determine cause and effect between independent and dependent variable. A common situation for implementing quasi-experimental study involves several classes or schools that can be used to determine the effect of curricular materials or teaching methods. In this study, pictures series was the independent variable which may cause/influence students' writing skill in narrative text as the dependent variable.The study was held at one of Senior Vocational high school located in Cianjur. The writer conducted the study about one month. The study was held in April 11th - 28th,2017 at the first semester of academic year 2016/2017.

\section{RESULTS AND DISCUSSION Results}

The data were collected from students' pre-test and pro-test of both classes. The data which is obstained is described into two tables. The table 4.1 showed the students' score and achievement in experiment class and the table 4.2 showed the students' score and achievement in control class. Each table has five columns; the first column showed the number of student, the second and the third column showed pre-test and post-test, and the last column showed the categorization in post test score.

Based on the calculation of normally, the writer got the result that all data in pre-test and posttest of both experiment class and controlled class have been normally distributed. The next step 
of the calculation was finding the homogeneity of the data. The purpose of this calculation was to see whether the data/sample in both classes were homogenous or heterogeneous.

The criteria of the test:

$$
\begin{aligned}
& \alpha=0.05 \\
& \mathrm{H}_{\mathrm{o}}: \mathrm{F} \alpha\left(\mathrm{n}_{1}-1, \mathrm{n}_{2}-2\right)<\mathrm{F}<\mathrm{F} \alpha\left(\mathrm{n}_{1}-1, \mathrm{n}_{2}-2\right) \\
& \mathrm{H}_{1}: \mathrm{F}>\mathrm{F} \alpha\left(\mathrm{n}_{1}-1, \mathrm{n}_{2}-2\right)
\end{aligned}
$$

The formula used can be seen as follows:

$$
\begin{gathered}
\mathrm{F}=\frac{\text { The Highes Variance }}{\text { The Lowes Variance }} \\
\text { Or } \\
F=\frac{S_{1}^{2}}{S_{2}^{2}}
\end{gathered}
$$

The calculation can be seen as follows:

$$
\begin{aligned}
F & =\frac{S_{1}^{2}}{S_{2}^{2}} \\
& =\frac{3.34}{12.71}=0.26
\end{aligned}
$$

$$
\begin{aligned}
& \mathrm{n}_{1}-1=39-1=38 \\
& \mathrm{n}_{2}-1=39-1=38 \\
& \mathrm{~F} 0.05\left(\mathrm{n}_{1}-1, \mathrm{n}_{2}-1\right)=1.69(\mathrm{~F} \text { table })
\end{aligned}
$$

From the calculation, it can be seen that $\mathrm{F}<\mathrm{F} \alpha\left(\mathrm{n}_{1}-1, \mathrm{n}_{2}-2\right)(0.26<1.69)$. Based on the criteria, it can be conclude that Ho is accepted. It means that,the sample in experiment class and controlled class were homogeneous.

\section{Discussion}

Based on the criteria, it means that the sample in experiment class and control class were homogenous. The final calculation was testing the hyphotesis. This was the main calculation to answer the problem formulation of this research that whether there is significant different between students' writing skill in narrative text at experiment class which using series of pictures. The writer used T-test formula in the significance degree $(\alpha)$ of $5 \%$. The result showed that ttest (to) $>$ t-table (tt) $(5.514>1.992)$. It means that alternative hypothesis $(\mathrm{Ha})$ is accepted that there is a significant difference between students' writing skill in narrative text by using series of pictures than without series of pictures.

The result is in line with the previous study conducted by Mansur (2011) who conducted a study about teaching English entitled"' Improving the Students Ability in writing Narrative Text 
through Series Picture at the Tenth Grade of SMA PGRI Tuban'. The result of the study showed that (1) the implementation of picture series in teaching narrative ttext is effective to use because it can attract the students and motivate theim in writing. It is also mentioned that through picture series, the students can get enough stimuli. The students also could show their opinion about the picture so they can express their ideas, (2) the students writing ability in narrative text after using picture series was improved in each aspect. The students could develop the content of the story and organized it based on the generic structure. They also used the proper vocabularies. It made the reader understood with the whole of the story. The average score in the first cycle was 65 , and the average score in the second cycle was 71 .

\section{CONCLUSION}

Based on the analysis result of this research, shows that the result of T-test formula to test the hyphotesis of this research. The result showed that in significance degree of 5\%, t-test (to) > ttable (tt) $(5.514>1.992)$. It means that,the result of ttest was higher than the result of ttable. So, the null hyphotesis (Ho) is rejected. It means that the answer of research problem was proven that the use of series of picture is effective for improving students' ability in writing narrative text.

After the writer carried out the research, the researcher would like to give some suggestion related to the result of the research and discussion. The result of this study showed that it is effective to be applied in teaching and learning process. There are some points that the research might suggest:

1. The teacher should use series of pictures towards students' writing skill in narrative text as a media to use in their writing. So students can produce better writing.

2. The teacher should motivate their students to keep learning and writing use a media. It is make this students more interested to create the sentences in writing narrative text which is unity, cohesive a guide and clarity based on the series of pictures.

3. The teacher should be more creative to find out the various themes of the narrative text. The narrative text is not only found at students' guide book, but the teacher can also find out in the narrative text collection in internet. It is better if the teacher select the story in narrative text that is interesting for students.

\section{ACKNOWLEDGMENTS}

Alhamdulillahirabbil 'alamin. Praise be to Allah SWT who has anabled the researcher to finish this paper. Peace and salutation go to Rasulullah SAW. Thanks to parents, family and our lecturers during the completing the paper the researcher obtained many helps, motivations and suggestions.

\section{REFERENCES}

Harmer, J. (1991). The Practice of English Language Teaching. New York: Longman Group. Heaton, J. B. (1995). Writing English Language Test. New York: Longman Inc.

Miller, R. K. (2006). Motivas For Writing (Fifth Edition). New York: The McGraw Hill Companies, Inc.

Mundriyah, M., \& Parmawati, A. (2016). Using Think-Pair-Share (Tps) To Improve Students'writing Creativity (A Classroom Action Research In The Second Semester Students Of Stkip Siliwangi Bandung). P2m Stkip Siliwangi, 3(2), 84-91. 
Oshima, A. \& A. H. (2007). Introduction to Academic Writing. New York: Pearson Education.

Pharr, D. and B. S. V. (2005). Writing Today: Contexts and Options for the Real Word. New York: The McGraw Hill - Companies.

Raimes, A. (1983). Techniques in Teaching Writing. New York: Oxford University Press.

Wright, A. (1989). Pictures for Language Learning. Cambridge: Cambridge University Press. 